Jurnal Tarbawi| Volume 1|No 1| ISSN 2527-4082| 1

\title{
TANTANGAN PENDIDIKAN ISLAM DI ERA GLOBALISASI
}

\author{
Mawardi Pewangi ${ }^{1}$ \\ Pendidikan Agama Islam Fakultas Agama Islam| Unismuh Makassar
}

\begin{abstract}
ABSTRAK
Studi ini bertujuan untuk mengidentifikasi dan menganalisis tantangan pendidikan Islam di era globalisasi. Pembahasan difokuskan pada bagaimana karakteristik era globalisasi? Bagaimana tantangan globalisasi terhadap pendidikan Islam? Bagaimana strategi pendidikan Islam dalam menghadapi tantangan globalisasi? Data diperoleh melalui studi kepustakaan kemudian dianalisis relevansinya dengan fakta aktual yang terjadi dewasa ini. Ada tiga tantangan utama yang kini dihadapi oleh pendidikan Islam, yaitu kemajuan iptek, demokratisasi, dan dekadensi moral. Pada intinya lembaga-lembaga pendidikan Islam harus mereformasi kurikulumnya agar dapat menyiapkan sumber daya manusia yang unggul dan memiliki daya saing dalam menghadapi kompetisi global.
\end{abstract}

Kata kunci: Tantangan pendidikan Islam, Globalisasi.

\begin{abstract}
This study aims to identify and analyze the challenges of Islamic education in the era of globalization. The discussion focused on how the characteristics of the era of globalization? How the challenges of globalization on Islamic education? How Islamic education strategy in facing the challenges of globalization? Data obtained through library research and analyzed their relevance to the actual facts that happened today. There are three main challenges now faced by the Islamic education, the advancement of science and technology, democratization, and moral decadence. At the core of Islamic educational institutions should reform the curriculum in order to prepare human resources for excellence and competitiveness in the face of global competition.
\end{abstract}

Keywords: Islamic educational challenges, globalization. 


\section{PENDAHULUAN}

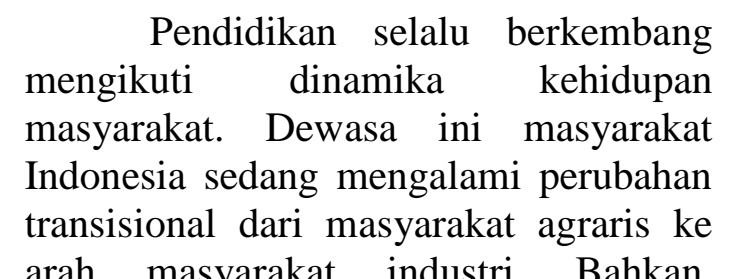
sebetulnya telah terjadi lompatan perubahan dari masyarakat agraris ke masyarakat informasi. Menurut Tilaar (2008: 90), perubahan tersebut meniscayakan desain pendidikan memiliki relevansi dengan kebutuhan masyarakat yang terus berubah. Artinya, pendidikan pada masyarakat agraris didesain relevan dengan dinamika dan kebutuhan masyarakat agraris. Pendidikan pada masyarakat industri dan informasi didesain mengikuti arus perubahan dan kebutuhan masyarakat era industri dan informasi. Begitulah siklus perkembangan perubahan pendidikan yang senantiasa didesain relevan dengan perubahan zaman dan kebutuhan masyarakat pada suatu era, baik pada aspek konsep, materi dan kurikulum, proses, fungsi serta tujuan dari lembaga pendidikan.

Pendidikan Islam sebagai bagian dari sistem pendidikan nasional, kini dihadapkan pada tantangan baru sebagai konsekuensi dari dinamika zaman yang disebut era globalisasi. Dalam menghadapi tantangan tersebut, diperlukan suatu strategi baru yang solutif dan antisipatif. Menurut Tilaar (1998: 245), apabila tantangan baru tersebut dihadapi dengan menggunakan strategi lama, maka segala usaha yang dijalankan akan menemui kegagalan. Hal ini menuntut para pemikir dan praktisi pendidikan Islam agar dapat menemukan strategi pendidikan Islam yang tepat untuk menghadapi kehidupan global.

Pendidikan Islam diartikan oleh Zakiah Darajat (1994: 28) sebagai aktivitas dan sistem pendidikan yang diselenggarakan atau didirikan untuk mengejawantahkan nilai-nilai ajaran Islam sehingga terbentuk pribadi muslim. Secara faktual, pendidikan Islam di Indonesia dikelompokkan oleh Ahmad Tafsir (2005: 24-25) menjadi lima jenis, yaitu: (1) pondok pesantren, (2) madrasah dan pendidikan lanjutannya, seperti UIN, (3) sekolah Islam (4) pelajaran agama Islam di sekolah dan perguruan tinggi, (5) pendidikan Islam dalam keluarga, masyarakat, dan juga melalui jalur nonformal dan informal. Berdasarkan uraian ini, maka istilah pendidikan Islam yang dimaksudkan dalam tulisan ini mencakup dua makna, yaitu pendidikan Islam sebagai lembaga dan sebagai proses penanaman nilai-nilai Islam.

Lembaga pendidikan Islam di Indonesia dalam pandangan Daulay (2004: 146) seharusnya lebih maju disebabkan social power yang dimilikinya. Ia berada di tengah wilayah yang memiliki penduduk muslim terbesar di dunia. Tetapi kenyataan menunjukkan sebaliknya, lembagalembaga pendidikan Islam tidak lebih unggul, bahkan reputasinya lebih rendah dibanding dengan yang lain.

Masalah pokok yang dibahas dalam makalah ini adalah bagaimana tantangan pendidikan Islam di era global? Adapun submasalahnya sebagai berikut: 
1. Bagaimana karakteristik era globalisasi?

2. Bagaimana tantangan globalisasi terhadap pendidikan Islam?

3. Bagaimana strategi pendidikan Islam dalam menghadapi tantangan globalisasi?

Kajian ini merupakan studi kepustakaan (library research). Data diperoleh dari literatur yang berbicara tentang pendidikan Islam dan kaitannya dengan tantangan globalisasi.

\section{HASIL DAN PEMBAHASAN Karakteristik Era Globalisasi}

Globalisasi berasal dari bahasa Inggris, yaitu globalization, dari akar kata global yang berarti sedunia atau sejagat (Echols, 1993:271). Jadi globalisasi dapat diartikan sebagai proses menjadikan sesuatu bersifat mendunia atau menjagat J. A. Scholte dikutip Zubaedi (2012: 97), membagi pengertian globalisasi menjadi lima kategori:

1. Globalisasi sebagai internasionalisasi, yaitu pertumbuhan dalam pertukaran dan interdependensi nasional.

2. Globalisasi sebagai liberalisasi, yaitu proses penghapusan hambatan-hambatan yang dibuat oleh pemerintah terhadap mobilitas antarnegara untuk menciptakan sebuah ekonomi dunia yang terbuka dan tanpa batas.

3. Globalisasi sebagai universalisasi, yaitu proses penyebaran berbagai objek dan pengalaman kepada semua orang ke seluruh penjuru dunia.
4. Globalisasi sebagai westernisasi atau modernisasi, yaitu sebuah dinamika yang menyebabkan struktur sosial modernitas (kapitalisme, rasionalisme, industrialisme, birokratisme, dan sebagainya) disebarkan ke seluruh penjuru dunia.

5. Globalisasi sebagai penghapusan batas-batas teritorial, yaitu mendorong rekonfigurasi geografis sehingga ruang sosial tidak lagi semata dipetakan dengan kawasan teritorial.

Proses globalisasi yang mengarah kepada terbentuknya global society itu, menurut Sadegh (1995: 9095), pada dasarnya ditandai dengan terjadinya berbagai kecenderungan, antara lain:

1. Perubahan konsep mengenai ruang dan waktu.

Perkembangan di bidang transportasi menimbulkan perubahan penting dalam konsep ruang dan waktu. Jarak antarkota, antarnegara, bahkan antarbenua tidak lagi diukur dengan kilometer melainkan dengan sekian jam penerbangan. Pemilikan alat komunikasi dan informasi yang berskala massif menambah semakin relatifnya pengertian 'dekat' dan 'jauh'. Inilah proses yang sering disebut sebagai timespace compression (pemadatan waktu dan ruang).

2. Volume interaksi sosial yang semakin meningkat.

Seiring dengan perkembangan teknologi transportasi yang terus meningkat, maka meningkat pula volume hubungan kultural antarbangsa. Secara bersamaan, melalui lembagalembaga pendidikan, berlangsung pula 
alih pengetahuan dan teknologi dengan daya jangkau yang makin luas. Penggunaan telepon, komputer, internet, dan telepon seluler telah mendekatkan mereka yang secara fisik saling berjauhan. Melalui media elektronik terbuka lebar kemungkinan bagi siapa saja untuk bersentuhan dengan gagasan dan pengalaman baru. Dalam proses ini, nilai-nilai budaya dari pihak yang lebih dominan dalam penguasaan iptek akan cenderung berposisi dominan pula dalam interaksi kultural yang terjadi.

3. Kesamaan problem penduduk dunia.

Interaksi antar penduduk dari berbagai belahan dunia, menghadapkan umat manusia kepada isu-isu yang sama, juga menyadarkan manusia bahwa apa yang terjadi di suatu pojok dunia dapat berpengaruh bahkan memiliki tali-temali dengan peristiwa di bagian dunia yang lain. Semakin banyak masalah yang terkait dan bersifat global, menyadarkan manusia bahwa untuk mengatasi masalah-masalah demikian tidak bisa lain kecuali dengan pendekatan yang juga bersifat global.

4. Saling hubungan dan saling ketergantungan yang semakin meningkat.

Banyak problem yang dihadapi secara bersama, mengikat orang dalam suatu kondisi saling berhubungan dan saling ketergantungan yang terus meningkat. Inilah yang disebut $a$ network society (masyarakat jaringan). Pendorong berkembangnya jaringanjaringan itu adalah pengetahuan dan informasi. Karena itu kekuatan dan kelemahan sebuah lembaga akan sangat ditentukan oleh kemampuannya memanfaatkan dan mengembangkan jaringan serta menguasai informasi.

Berdasarkan pengertian di atas, maka globalisasi merupakan sebuah proses sosial yang berakibat pembatasan geografis dan keadaan sosial budaya menjadi hilang. Globalisasi menyatukan masyarakat yang sebelumnya terpencarpencar dan terisolasi ke dalam saling ketergantungan dan persatuan dunia. Globalisasi menyangkut seluruh proses yang menghubungkan penduduk dunia ke dalam komunitas dunia (global society) yang tunggal, bagaikan hidup di sebuah desa, yaitu desa dunia (global village).

Globalisasi pada awalnya dipicu oleh kemajuan teknologi, khususnya di bidang transportasi dan komunikasi, tetapi dampaknya segera meluas ke berbagai bidang kehidupan, baik ekonomi, politik, budaya, bahkan agama. Globalisasi menjadi sebuah fenomena yang kompleks dan berefek luas. Tidak mengherankan, jika istilah globalisasi ini telah memperoleh konotasi arti yang banyak. Globalisasi di satu sisi dipandang sebagai kekuatan tak tertahankan yang memberi kemakmuran ekonomi kepada orang-orang di seluruh dunia, tetapi di sisi lain, ia dituding sebagai sumber dari malapetaka manusia modern.

Menurut Sadegh (1995: 97), globalisasi menjadi petaka karena dapat melahirkan frustasi eksistensial (existential frustation) yang dicirikan dengan hasrat yang berlebihan untuk berkuasa (the will to power), mengumpulkan uang (the will to money), untuk bekerja (the will to work), dan kenikmatan seksual (the will to sex). Keseluruhan hasrat ini merupakan 
turunan dari materialisme dan hedonisme.

Globalisasi yang bersumber dari Barat, dewasa ini tampil dengan watak hegemonik di bidang politik, ekonomi, teknologi, dan kultural. Akibatnya, pendidikan Islam sebagai upaya pewarisan nilai-nilai Islam, kini dihadapkan pada desakan dan agresi nilai-nilai dan budaya Barat.

Salah satu ciri dari globalisasi menurut Mastuhu (1999: 275) adalah kompetisi, dan syarat untuk memenangkan sebuah kompetisi adalah keunggulan. Di sini letak tantangan bagi pendidikan Islam untuk dapat terus eksis dan menjadi pilihan masyarakat di era mendatang. Pendidikan Islam juga ditantang untuk menghasilkan produk (generasi muslim) yang berkualitas dan berdaya bersaing tinggi dengan tetap memelihara ciri keislamannya.

\section{Beberapa Tantangan Pendidikan Islam}

Tantangan globalisasi merupakan suatu kondisi kekinian sebagai akibat dari modernisasi. Kondisi tersebut harus dihadapi dan dilalui agar tercapai suatu keberhasilan. Tantangan tidak harus dimaknai sebagai sesuatu yang membuat sulit, atau kadang menghambat sesuatu yang ingin dicapai, tetapi tantangan adalah penggugah tekad untuk meningkatkan kemampuan menyelesaikan masalah.

Mastuhu

(1999:

mengemukakan, beberapa tantangan yang dihadapi dunia pendidikan masa kini, yaitu globalisasi, kompleksitas, turbulence, dinamika, akselerasi, keberlanjutan dari yang kuno ke yang modern, koneksitas, konvergensi, konsolidasi, rasionalisme, paradoks global, dan kekuatan pemikiran.

Selajutnya, Rahim (2001: 14) mengemukakan bahwa secara eksternal masa depan pendidikan Islam dipengaruhi oleh tiga isu besar, yaitu globalisasi, demokratisasi, dan liberalisme Islam. Daulay (2004: 139) menyebut globalisasi, kemajuan ilmu pengetahuan dan teknologi, dan dekadensi moral sebagai tantangan pendidikan Islam masa kini dan masa depan. Sedangkan Wahid (2011: 60) mengemukakan, tantangan pendidikan Islam yang harus dihadapi di era global ini adalah kebodohan, kebobrokan moral, dan hilangnya karakter muslim.

Keempat pakar di atas berbeda dalam mengidentifikasi tantangan pendidiikan Islam karena berbeda sudut pandang yang digunakan. Mastuhu melihatnya dalam perspektif perubahan sosial, Rahim mengamati menurut tinjauan politik, Daulay melihatnya dalam sudut pandang perkembangan iptek, dan Wahid melihatnya dari sudut pandang etika.

Menurut Zubaedi (2012: 54), ketika globalisasi dihadapkan dengan pendidikan Islam, maka muncul dua implikasi sekaligus, yakni peluang dan ancaman. Sebagai peluang, globalisasi di satu sisi akan memudahkan pendidikan Islam untuk mengakses berbagai informasi secara cepat, juga memudahkan pendidikan Islam untuk menyebarluaskan produk-produk keilmuan yang memberikan manfaat bagi masyarakat. Selanjutnya sebagai ancaman, ternyata globalisasi tidak hanya mempengaruhi tatanan kehidupan pada tataran makro, tetapi juga mengubah tata kehidupan pada level 
mikro, yaitu terhadap ikatan kehidupan sosial masyarakat. Globalisasi memicu fenomena disintegrasi sosial, hilang nilai-nilai tradisi, adat-istiadat, sopan santun, dan penyimpangan sosial lainya.

Merujuk kepada berbagai pendapat di atas, penulis memilah dan merumuskan tiga tantangan utama untuk dibahas. Ketiga tantangan ini dianggap memiliki pengaruh paling krusial terhadap pendidikan Islam. Adapun tantangan yang lainnya adalah implikasi yang lahir dari adanya ketiga tantangan utama tersebut.

1. Kemajuan Ilmu Pengetahuan dan Teknologi.

Pendidikan Islam saat ini sedang ditantang konstribusinya terhadap pembentukan peradaban dan budaya modern yang relevan dengan perkembangan ilmu pengetahuan, teknologi, dan seni (ipteks). Pada dimensi ini, pendidikan Islam mengalami kemunduran fungsi (degradasi fungsional) karena pendidikan Islam lebih berorientasi pada aspek moral spiritual.

Terdapat banyak pendapat yang mengatakan bahwa pendidikan Islam tidak terlalu fokus memprioritaskan aspek yang bersifat praktis dan pragmatis, seperti penguasaan teknologi. Akibatnya, pendidikan Islam tidak mampu bersaing pada level kebudayaan di tingkat global.

$$
\text { Secara makro kondisi }
$$

pendidikan Islam saat ini sudah ketinggalan zaman. Tertinggal karena kalah berpacu dengan perkembangan dan perubahan sosial budaya. Tertinggal sebab alumni yang hasilkan kalah bersaing dalam penguasaan ipteks. Ipteks dengan beragam kemajuan yang dibawanya bersifat fasilitatif terhadap kehidupan manusia. Artinya, ipteks memberi fasilitas kemudahan bagi manusia, tetapi juga dapat merugikan.

Berdasarkan uraian di atas, dapat disimpulkan bahwa pendidikan Islam memandang perkembangan ipteks sebagai tantangan yang harus dihadapi dan dikuasai, sehingga generasi muslim tidak tertinggal oleh kebudayaan yang berkembang. Pada konteks ini ada dua hal yang penting untuk dipikirkan, yaitu (1) bagaimana supaya perkembangan ipteks tidak terlepas dari nilai-nilai ajaran Islam; (2) bagaimana pendidikan Islam dapat berkonstribusi bagi kemajuan ipteks di masa depan.

2. Demokratisasi

Demokratisasi merupakan isu lain yang mempengaruhi pendidikan Islam Indonesia. Dede Rosyada (2004) menjelaskan, bahwa tuntutan demokratisasi pada awalnya ditujukan pada sistem politik negara sebagai antitesis terhadap sistem politik yang otoriter. Selanjutnya perkembangan tuntutan ini mengarah kepada sistem pengelolaan berbagai bidang termasuk bidang pendidikan.

Kehidupan demokrasi adalah kehidupan yang menghargai akan potensi individu. Artinya, bahwa setiap bentuk homogenisasi masyarakat adalah bertentangan dengan prinsip-prinsip hidup demokrasi. Sehingga, menurut Tilaar (1998), dalam bidang pendidikan semua warga negara memiliki hak yang sama untuk memperoleh pendidikan, juga memiliki kewajiban yang sama dalam membangun pendidikan nasional yang berkualitas. Demokratisasi pendidikan membuka ruang partisipasi publik untuk terlibat dalam pendidikan, 
walaupun di satu sisi ini berpotensi melahirkan komersialisasi pendidikan, terutama oleh kelompok pengusaha pendidikan yang berusaha meraup keuntungan melalui bisnis pendidikan.

Demokratisasi pendidikan Islam menghendaki sistem pendidikan yang bersifat sentralistik, seragam, dan dependen, untuk beralih mengembangkan sistem pendidikan yang lebih otonom, beragam, dan independen.

3. Dekadensi moral

Revolusi teknologi berakibat pada pergeseran nilai dan norma budaya. Pada lazimnya, nilai-nilai budaya dari pihak yang lebih dominan dalam penguasaan ipteks akan cenderung berposisi dominan pula dalam interaksi kultural yang terjadi. Dalam konteks ini, Hasbi Indra (2005: 72) menjelaskan bahwa budaya Barat telah memperlihatkan superioritasnya terhadap budaya Islam. Produk teknologi seperti TV, parabola, telepon, VCD, DVD, internet, dan lain-lain dapat membuka hubungan dengan dunia luar sehingga wawasan masyarakat terbuka. Namun, lewat media tersebut dapat pula disaksikan pornografi, film-film, sinetron yang menawarkan gaya hidup bebas dan juga kekerasan, yang secara moral bertentangan dengan nilai Islam.

Berdasarkan uraian di atas, jelas tidak dapat dipungkiri bahwa perubahan dalam segala bentuk, baik bersifat personal maupun global bisa terjadi dalam hitungan waktu yang relatif sangat singkat. Hal ini merupakan tantangan yang mutlak dijawab oleh pendidikan Islam melalui strategi yang tepat.
Strategi Pendidikan Islam di Indonesia Menghadapi Globalisasi.

Menghadapi

tantangan

globalisasi seperti yang dikemukakan di atas, pendidikan Islam perlu melakukan langkah-langkah strategis dengan membenahi beberapa persoalan internal.

Persoalan internal yang dimaksud adalah: (1) persoalan dikotomi pendidikan; (2) tujuan dan fungsi lembaga pendidikan Islam; (3) persoalan kurikulum atau materi. Ketiga persoalan tersebut saling terkait antara satu dengan yang lain.

1. Menyelesaikan persoalan dikotomi

Persoalan dikotomi ilmu agama dan ilmu umum melahirkan dualisme pendidikan, yaitu pendidikan Islam dan pendidikan umum. Dikotomi dan dualisme merupakan persoalan lama yang belum terselesaikan sampai sekarang.

Seiring dengan itu berbagai istilah pun muncul untuk membenarkan pandangan dikotomis tersebut. Misalnya, adanya fakultas umum dan fakultas agama, sekolah umum dan sekolah agama. Dikotomi itu menghasilkan kesan bahwa pendidikan agama berjalan tanpa dukungan ipteks, dan sebaliknya pendidikan umum hadir tanpa sentuhan agama.

Pendidikan Islam harus menuju pada integrasi antara ilmu agama dan ilmu umum. Fazlur Rahman (1985: 160) menawarkan satu pendekatan untuk menyelesaikan persoalan dikotomi pendidikan yaitu dengan menerima pendidikan sekuler modern sebagaimana yang berkembang di dunia Barat dan mencoba untuk mengisinya dengan konsep-konsep kunci tertentu dari Islam. 


\begin{abstract}
Ahmad Syafi'i Ma'arif (1991:150) mengatakan bila konsep dualisme dikotomik berhasil diselesaikan, maka dalam jangka panjang sistem pendidikan Islam akan berubah secara keseluruhan, mulai dari tingkat dasar sampai ke perguruan tinggi. Pendidikan Islam melebur secara integratif dengan pendidikan umum. Peleburan bukan hanya dalam bentuk satu departemen saja, tetapi lebur berdasarkan kesamaan rumusan filosofis dan pijakan epistemologisnya.

Upaya intergrasi keilmuan di Indonesia dapat dilihat dengan perubahan kelembagaan perguruan tinggi Islam dari insitut menjadi universitas. Pada level madrasah dan pondok pesantren upaya ini diwujudkan dengan memasukkan mata pelajaran umum dalam kurikulum.
\end{abstract}

2. Revitalisasi tujuan dan fungsi

lembaga pendidikan Islam.

Lembaga-lembaga pendidikan Islam perlu mendisain ulang tujuan dan fungsinya. Menurut Azyumardi Azra (1999: 71-72) terdapat beberapa model pendidikan Islam di Indonesia:

a. Pendidikan

Islam

mengkhususkan diri pada

pendidikan keagamaan saja untuk mempersiapkan dan melahirkan ulama-mujtahid yang mampu menjawab persoalanpersoalan aktual atau kontemporer sesuai dengan perubahan zaman.

b. Pendidikan Islam yang mengintegrasikan kurikulum dan materi-materi pendidikan umum dan agama, untuk mempersiapkan intelektual Islam yang berpikir secara komprehensif, contohnya madrasah.

c. Pendidikan Islam meniru model pendidikan sekuler modern dan mengisinya dengan konsepkonsep Islam, contohnya sekolah Islam.

d. Pendidikan Islam menolak produk pendidikan Barat. Hal ini berarti harus mendisain model pendidikan yang betul-betul orisinil dari konsep dasar Islam dan sesuai dengan lingkungan sosial-budaya Indonesia.

e. Pendidikan agama tidak dilaksanakan di sekolah-sekolah tetapi dilaksanakan di luar sekolah. Artinya, pendidikan agama dilaksanakan di rumah atau lingkungan keluarga dan lingkungan masyarakat.

Model tersebut dapat dipilih untuk diterapkan yang penting sejalan dengan kebutuhan masyarakat muslim. Pada intinya, menurut Nata (2003: 78), pendidikan Islam harus mampu menyiapkan sumber daya manusia yang dapat berpikir kritis dengan fokus dan tidak hanya sebagai penerima informasi global, tetapi juga harus memberikan bekal kepada peserta didik agar dapat mengolah, menyesuaikan, dan mengembangkan segala hal yang diterima melalui arus informasi tersebut, yakni manusia yang kreatif dan produktif.

3. Reformasi kurikulum atau materi Materi pendidikan Islam terlalu didominasi masalah-maslah yang bersifat normatif, ritual dan eskatologis. Malik Fajar (1998: 5) menjelaskan, materi pendidikan Islam disampaikan 
dengan semangat ortodoksi keagamaan, tanpa ada peluang untuk melakukan telaah secara kritis. Pendidikan Islam tidak fungsional dalam kehidupan sehari-hari, kecuali hanya sedikit aktivitas verbal dan formal yang bersifat ritual.

\section{Berdasarkan pengembangan} keilmuan, dari berbagai problem yang muncul di atas, jelas tidak bisa direspon hanya dengan ilmu-ilmu yang selama ini ada di lembaga pendidikan Islam, seperti fiqih, ilmu kalam, tasawuf, aqidah akhlak, dan tarikh. Ilmu-ilmu tersebut perlu kembangkan sehingga mampu menjawab persoalan aktual, misalnya masalah lingkungan hidup, global warming, pencemaran limbah beracun, penggundulan hutan, gedung pencakar langit, polusi udara, dan problem sosial, antara lain: banyaknya pengangguran, penegakan hukum, hak asasi manusia, korupsi, dan sebagainya.

Dalam konteks ini, materi pendidikan Islam secara garis besar diarahkan pada dua dimensi, yakni: (1) dimensi vertikal berupa ajaran ketaatan kepada Allah swt. dengan segala bentuk artikulasinya; (2) dimensi horizontal berupa pengembangan pemahaman tentang kehidupan manusia dalam hubungannya dengan alam atau lingkungan sosialnya. Dimensi yang kedua ini dilakukan dengan mengembangkan materi pendidikan yang berorientasi pada penguasaan ilmu pengetahuan dan teknologi.

Tiga hal yang dikemukakan di atas merupakan tawaran desain pendidikan Islam yang perlu diupayakan untuk membangun pendidikan Islam yang bermutu di tengah kehidupan global yang kompetitif. Ketiga hal tersebut masih membutuhkan unsur lain sebagai pendukung, seperti sumber daya kependidikan yang berkualitas, pendanaan yang memadai, dan lingkungan sosial yang kondusif.

\section{KESIMPULAN}

1. Globalisasi menyebabkan penduduk dunia berbaur dan menyatu dalam pergaulan yang lintas batas dan lintas budaya. Bidang-bidang kehidupan pun dibuat saling terkait satu sama lain. Globalisasi melahirkan saling ketergantungan, sekaligus menghadirkan persaingan di semua lini kehidupan.

2. Ada tiga tantangan utama yang kini dihadapi oleh pendidikan Islam, yaitu kemajuan iptek, demokratisasi, dan dekadensi moral. Ketiga tantangan tersebut membawa pengaruh besar dalam semua bidang kehidupan manusia, termasuk bidang pendidikan. Perkembangan dan kemajuan iptek prinsipnya berpotensi melemahkan daya mental spiritual. Permasalahan baru yang harus segera dipecahkan oleh pendidikan Islam adalah dehumanisasi pendidikan dan netralisasi iptek dari nilai-nilai agama. Pendidikan Islam ditantang untuk membuktikan kemampuannya dalam penguasaan iptek, sekaligus kesanggupannya dalam mengendalikan dampak negatif dari iptek.

3. Menghadapi tantangan modernitas, pendidikan Islam harus melakukan langkah strategis dengan terlebih dahulu membangun paradigma keilmuan yang integratif sebagai 
jawaban terhadap dikotomi ilmu. Lembaga-lembaga pendidikan Islam juga mendisain ulang fungsinya dengan memilih model pendidikan yang relevan dengan perubahan zaman dan kebutuhan masyarakat. Pilihan yang paling tepat adalah mengadaptasi model pendidikan modern (Barat) dalam sistem pendidikan Islam. Pilihan ini bukan berarti sekularisasi atau westernisasi, tetapi pilihan ini tetap meniscayakan nilai-nilai Islam terpelihara dalam aktivitas pendidikan Islam. Tahap selanjutnya, lembaga-lembaga pendidikan Islam harus mereformasi kurikulumnya agar dapat menyiapkan sumber daya manusia yang unggul dan memiliki daya saing dalam menghadapi kompetisi global.

\section{DAFTAR PUSTAKA}

Azra, Azyumardi. 1999. Pendidikan Islam: Tradisi dan Modernisasi Menuju Milenium Baru. Cet. 1; Jakarta: Logos Wacana Ilmu.

Daulay, Haidar Putra. 2004. Pendidikan Islam dalam Sistem Pendidikan Nasional. Cet. 1; Jakarta: Kencana.

Darajat, Zakiah. Ilmu Pendidikan Islam. Jakarta: Bumi Aksara, 1994.

Echols, John M. Echols dan Hassan Shadily. 1993. Kamus InggrisIndonesia. Cet. XIX; Jakarta: PT Gramedia.

Fajar, A. Malik. 1998. Madrasah dan Tantangan Modernitas. Bandung: Mizan.

Reformasi Pendidikan dan
Pengembangan Sumber Daya
Manusia. Jakarta: Logos Wacana
Ilmu.
Indra, Hasbi. 2005. Pendidikan Islam
Melawan Globalisasi. Cet. II;
Jakarta: Rida Mulia.

Maarif, Ahmad Syafi'i. 1991. "Pemikiran tentang Pembaharuan Pendidikan Islam di Indonesia," dalam Muslih Usa, ed., Pendidikan Islam di Indonesia antara Cita dan Fakta. Yogyakarta: Tiara Wacana.

Mastuhu, 1999. Memberdayakan Sistem Pendidikan Islam. Cet. 2; Jakarta: Logos Wacana Ilmu.

Nata, Abuddin. 2003. Manajemen Pendidikan, Mengatasi Kelemahan Pendidikan Islam di Indonesia. Bogor: Kencana.

Rahim, Husni. 2001. Arah Baru Pendidikan Islam di Indonesia (Cet. 1; Jakarta: Logos Wacana Ilmu.

Rahman, Fazlur. Islam and Modernity, Transformation of an Intellectual Tradition, terj. Ahsin Mohammad, Islam dan Modernitas. Yogyakarta: Pustaka, 1985.

Rosyada, Dede. 2004. Paradigma Pendidikan Demokratis: Sebuah Model Pelibatan Masyarakat dalam Penyelenggaraan Pendidikan. Cet. 1; Jakarta: Kencana. 
Sadegh, Bakhtiari. 1995. Globalization and Education Challenges and Opportunities. Iran: Journal Isfahan University.

Tafsir, Ahmad. 2005. Ilmu Pendidikan Islam dalam Perspektif Islam. Cet. 6; Bandung: PT. Remaja Rosdakarya.

Tilaar, H.A.R. 2008. Manajemen Pendidikan Nasional: Kajian Pendidikan Masa Depan. Cet. 9; Bandung: PT. Remaja Rosdakarya. 1998. Beberapa Agenda Reformasi Pendidikan Nasional dalam Perspektif Abad 21. Magelang: Tera Indonesia.

Wahid, Marzuki. 2011. Pesantren Masa Depan: Wacana Pemberdayaan dan Transformasi. Bandung: Pustaka Hidayah.

Zubaedi. 2012. Isu-Isu Baru dalam Diskursus Filsafat Pendidikan Islam dan Kapita Selekta Pendidikan Islam. Cet. I; Yogyakarta: Pustaka Pelajar. 